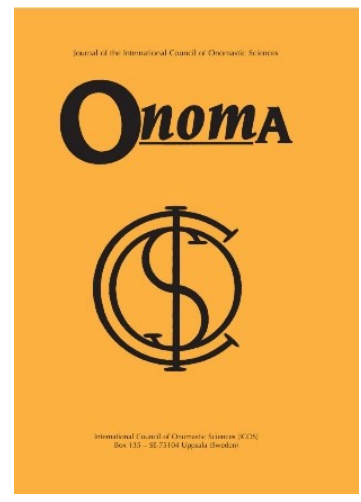

Onoma 54

Journal of the International Council of Onomastic

Sciences

ISSN: 0078-463X; e-ISSN: 1783-1644

Journal homepage: https://onomajournal.org/

\title{
Indo-Iranian personal names in Mitanni: A source for cultural reconstruction
}

DOI: $10.34158 /$ ONOMA.54/2019/8

\author{
Simone Gentile \\ Università degli Studi di Roma Tre \\ Dipartimento di Filosofia, Comunicazione e Spettacolo \\ via Ostiense, 234-236 \\ 00146 Roma (RM) \\ Italy \\ simone.gentile@uniroma3.it
}

To cite this article: Gentile, Simone. 2019. Indo-Iranian personal names in Mitanni: A source for cultural reconstruction. Onoma 54, 137-159. DOI: 10.34158/ONOMA.54/2019/8

To link to this article: https://doi.org/10.34158/ONOMA.54/2019/8

(C) Onoma and the author.

Indo-Iranian personal names in Mitanni: A source for cultural reconstruction

Abstract: As is known, some Indo-Aryan (or Iranian) proper names and glosses are attested in documents from Egypt, Northern Mesopotamia, and Syria, related to the ancient kingdom of Mitanni (2nd millennium BC). The discovery of these Aryan archaic forms in Hittite and Hurrian sources was of particular interest for comparative philology. Indeed, some names can be readily compared to Indo-Iranian anthroponyms and theonyms: for instance, Aššuzzana can likely be related with OPers. Aspačanā 'delighting in horses', probably of Median origin; Indaratti 'having Indra as his guest' clearly recalls Indra, a theonym which occurs both in Rgveda and Avesta. This paper aims at investigating the relationship between Aryan personal names preserved in Near Eastern documents and the Indo-Iranian cultural milieu. After a thorough collection of these names, their 
morphological and semantic structures are analysed in depth and the most relevant results are showed here. Moreover, a new typology of anthroponyms comes to light. Mitanni-Aryan names might therefore provide some relevant information concerning the Indo-Iranian cultural background before its split, as well as royal, religious and political ideology, despite the fragmentary documentation.

Keywords: Personal names, Mitanni, Old Indo-Iranian languages, cultural reconstruction.

\section{Les noms propres indo-iraniens dans le royaume de Mitanni : Aux sources de la civilisation indo-iranienne}

Résumé : Certains noms propres et lexèmes d'origine indo-iranienne témoignant de la période du royaume de Mitanni ( $2^{\text {ème }}$ millénaire av. J.-C.) sont connus depuis les régions de la Haute Mésopotamie et de la Syrie jusqu'à l'Égypte. Ainsi se révèle l'existence d'une civilisation arienne au Proche-Orient ancien. En effet, beaucoup d'anthroponymes sont superposables aux noms, titres ou épithètes iraniens et védiques: par exemple, Aššuzzana correspond au nom vieux perse Aspačanā ('[celui] qui aime bien les chevaux'), peut-être d'origine mède ; Indaratti ('[celui] qui a pour hôte Indra') se réfère certainement à Indra, nom propre d'une divinité aussi bien védique qu'avestique. Cet article vise à mettre en relation les anthroponymes ariens au Proche-Orient ancien avec le milieu culturel aryen. Est proposée d'abord une explication morphosémantique qui plonge ses racines dans la tradition poétique la plus ancienne des langues indo-iraniennes. De plus, une nouvelle typologie des noms propres est présentée. Malgré les limites objectives de cette documentation, il est toutefois possible d'identifier des traits archaïques de la société et de l'idéologie des peuples aryens à travers l'anthroponymie.

Mots-clés : Noms propres, Mitanni, langues indo-iraniennes anciennes, reconstruction culturelle.

\section{Indoiranische Personennamen aus Mitanni: eine mögliche kulturelle Rekonstruktion}

Zusammenfassung: Bekanntlich erscheinen indoiranische Eigennamen und Glossen in Texten aus Ägypten, Nordmesopotamien und Syrien, die das alte Mitanni Reich aus dem 2. Jahrhundert betreffen. Da diese archaische Formen des Arischen in die hethitische Sprache und das Hurritische betreffenden Dokumenten herausgefunden worden sind, werden sie von der vergleichenden Sprachwissenschaft als sehr interessant betrachtet. Substantive des Hethitischen und des Hurritischen scheinen z. B. mit Personennamen und Götterbezeichnungen auf Arisch verbunden zu sein. Der Name ,Ǎšsuzzana‘ könnte vielleicht aus dem medischen ,Aspačanā‘ stammen, bzw. „Einer, der sich mit den Pferden vergnügt“, während ,Indaratti ${ }^{\star}-d$. h. „Einer, der Indra zu Gast hat" - einfach die Göttinbezeichnung erinnern kann, die man sowohl im Rigveda als auch im Awesta erscheint. Hauptzweck dieses Referats ist nämlich über das Verhältnis zwischen den in den Mittlerer Osten Dokumenten erscheinenden Eigennamen auf Indoiranisch und dem indoiranischen sozialen Milieu nachzudenken. Nachdem alle die interessantesten Namen und Substantive herausgefunden zu haben, wird es möglich sein, sie detailliert unter einem morphologischen Gesichtspunkt und unter einem semantischen zu analysieren. Die wichtigsten und die anregendsten Ergebnisse dieser Forschung werden danach in diesem Referat aufgezeigt und erklärt. Darüber hinaus ist es möglich, über einen weiteren, interessanten, Vorteil dieser Namen zu reflektieren: die 
indoiranischen (Eigen-)Namen aus der Mitannizeit können trotz des unvollständigen Belegmaterials wichtige Informationen über den kulturellen und den politischen indoiranischen Hintergrund bieten können, wie z. B. über die königliche Ideologie sowie über die ökonomische und soziale Lage der Gesellschaft, bzw. in einer Epoche bevor der Splittung der indoiranischen linguistischen Gemeinsprache.

Schlüsselbegriffe: Personennamen, Mitanni Reich, alten indoiranische Sprachen, kulturelle Rekonstruktion. 


\title{
Indo-Iranian personal names in Mitanni: A source for cultural reconstruction
}

\author{
SIMONE GENTILE
}

\section{Introduction}

At the beginning of the 20th century some Indo-Aryan (or Iranian ${ }^{1}$ ) proper names and glosses were found in documents from Egypt, Northern Mesopotamia and Syria, mainly from the land of the Hurrian reign of Mitanni (also, Mitanni; 2nd millennium BC). These language fossils occur in Hittite, Egyptian and Hurrian documents concerning the kingdom of Mitanni: el-Amarna letters (14th century BC), a treaty between the Hittites and Mitanni (ca. 1380 BC), a hippological treatise by Kikkuli, a Hurrian master horse trainer (14th century BC), and Hurro-Akkadian tablets from Nuzi and other sites (14th century BC). This fact is not surprising if we consider that in the 16th century $\mathrm{BC}$ the kingdom of Mitanni became one of the greatest powers in the Near East, rivalling the Hittites, the Assyrians and the Egyptians (see Figure 1 below). ${ }^{2}$

These names and glosses aroused interest among scholars, leading then to hypothesize their close connection with the Indo-Aryan branch (Mayrhofer 1966, 1974; Eichner 2009), despite some scepticism (Kammenhuber 1968; Diakonov 1972). ${ }^{3}$

Interestingly, Mitanni rulers used to take an Aryan name when they ascended the throne (e.g. Artatama, Tušratta). ${ }^{4}$ Furthermore, Aryan personal names were also borne by other rulers, such as the kings of Kizzuwatna - an ancient Anatolian kingdom in the 2nd millennium BC - and some members of the ruling elites in Syria and Palestine.

In addition, in the treaty between Šuppiluliuma, king of the Hittites, and Šattiwaza, king of Mitanni, some (Indo-)Aryan deities are mentioned among the numerous tutelary deities of Mitanni (Thieme 1960; Beckman

1 Some scholars argued that these names could be Iranian according to a parallel with Achaemenid regnal names (Meyer 1908). However, the hypothesis has been rejected since these names show conservative Indo-Aryan traits (Mayrhofer 1966).

2 Further information on Mitanni kingdom can be found in Wilhelm (1995), Freu (2003), Cancik-Kirschbaum et al. (2014).

3 Following Thieme (1960: 302, fn. 7), in this paper, I will use the label Aryan as a neutral umbrella term, since it is debated whether these language forms derive from Proto-IndoIranian or Proto-Indo-Aryan.

$4 \quad$ See $\S 3$ for a tentative analysis of these names. 
1996: 37 ff.). Four deities are invoked to be divine witnesses of the treaty, respectively Mitra (mi-it-ra-), Varuna (a-ru-na- and ú-ru-ua-na-), Indra (in-da-ra-), and the charioteer twins, called Nāsatyas (na-aš-ša-at-ti-ia-). ${ }^{5}$ The same sequence of deities is found in a hymn from the Rgveda, the most ancient sacred book in India, as firstly noticed by Dumézil (1952: 9):

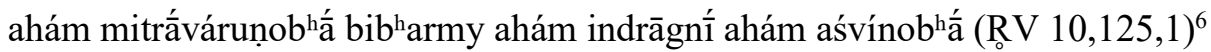
"I bear both Mitra and Varuṇa, I Indra and Agni, I both the Aśvins." (Jamison \& Brereton 2014: 1603)

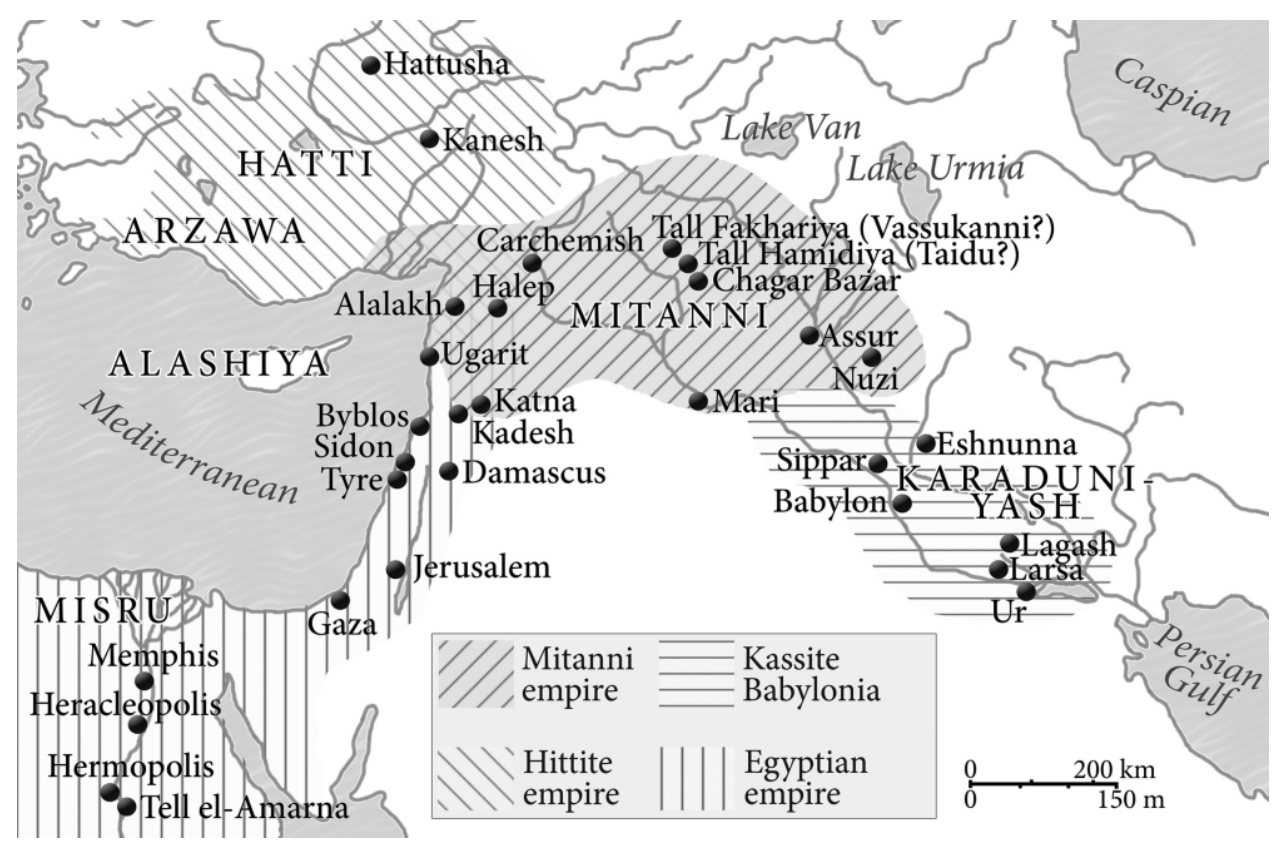

Figure 1: The Mitanni empire and its neighbours.

Map (C) Anna Kurvinen \& Asko Parpola after Parpola (2015: 85, Figure 8.9)

Although Aryan names, as aforementioned, are relatively widespread, also Hurrian names occur commonly in Egyptian, Hurrian, and Hittite sources (Gelb et al. 1943; Draffkorn 1959; Laroche 1966: 343 ff.; Cassin \& Glassner 1977; Giorgieri 1999). Indeed, the king and the members of the royal family kept Hurrian names. For instance, before his ascension to the throne, Šattiwaza was named Kili-teššup, while Kelu-h̆epat and Tatu-ḩepat, daughters respectively of the king Šuttarna II and the king Tušratta, bore undoubtedly Hurrian names. Accordingly, van Koppen (2004: 23, fn. 87) wonders whether Aryan names are original or secondary traits of the Mitanni state.

5 Throughout Vedas the divine charioteers are mainly referred to as Aśvins (for instance, Gotō 2009 and Pirart 1995: 23 ff.).

6 A list of abbreviations is given at the end of the article, after the Appendix, whereas abbreviations for individual bibliographical entries can be found in the References section. 
As a matter of fact, it is not yet clear whether (Indo-)Aryan people played an important role in the formation of the Mitanni state (Wilhelm 1989). As von Dassow (2014: 13) remarks:

While the practice of bestowing throne names of Indo-Aryan derivation on most of Mittani's kings suggests significant contact with an Indo-Aryanspeaking population, it does not indicate that the royal dynasty (much less the ruling class) was of Aryan "blood" - whatever that might mean.

Historical sources mention neither the Aryan ethnonym (cf. Ved. árya-, Av. $a^{i}$ riia-, OPers. ariya-) nor any Aryan diaspora in the ancient Near East (von Dassow 2008: 77 ff.). Consequently, it is unlikely that an Aryan elite was ruling over Hurrian principalities during 2nd millennium BC, even if Aryan names are noticeably attested.

Considering these premises, in this paper I will deal with Aryan onomastic evidence from the Near East during the 2nd millennium BC. The questions to be addressed are essentially two: i) What can Mitanni-Aryan names tell us? ii) Which key concepts do they convey?

This paper is structured as follows. At first, I will tackle some crucial preliminary issues $(\S 2)$. Therefore, I will focus on some Aryan names which could provide useful clues as to cultural reconstruction $(\S 3)$. Finally, I will briefly discuss the results $(\S 4)$.

\section{Some preliminary issues}

Mitanni-Aryan appellatives and names were firstly collected by the Belgian Indologist Paul-Émile Dumont (apud O'Callaghan 1948: 149 ff.). Manfred Mayrhofer has rounded off the work and added some other Aryan personal names from the ancient Near Eastern documentation (1965: $161 \mathrm{ff}$; 1966), ${ }^{7}$ focusing on them in several occasions (Mayrhofer 1974, 1982b).

Anyhow, the morphological and semantic structure of Mitanni-Aryan names is sometimes ambiguous, for two coexisting reasons. On the one hand, they are attested in different varieties of the cuneiform writing, which do not represent a one-to-one mapping between graphemes and phonemes. This leads to the fact that the same sequence of graphemes could be associated with different phonetic sequences. ${ }^{8}$ On the other hand, the structure of the

7 In my MA dissertation, I have discussed these names and provided an up-to-date list (Gentile 2018: 43 ff., 66 ff.). For the sake of brevity, in this paper I will focus only on some notable examples. In any case, I will list all the actual Aryan names in Appendix.

8 Not to mention that Aryan names could not be exactly reproduced in cuneiform writing. The underlying sound systems differ radically and foreign sounds are always liable to be misperceived by their hearers. This situation was even more difficult at Nuzi, since Hurrian scribes failed to distinguish between voiced and voiceless obstruents (Gelb et al. 1943: 194). 
compound names can be interpreted in different ways. For instance, a name such as Biridašwa, a mayor of Damascus, is graphically either bi-ri-ia-aš-šu-ua at Alalah or bi-ri-da-aš-ua in the el-Amarna letters (particularly at EA 196: 41; 197: 7, 15, 33). ${ }^{9}$ Indeed, this name could be interpreted in several ways. Dumont (apud O'Callaghan 1948: 151, no. 53) remarks that it goes back etymologically to Early Indo-Aryan *vrdd $\bar{a} s v^{\prime} a-$, which could be compared to Epic Sanskrit brhadaśva- 'having great horses'. Nonetheless, *vrdd $\bar{a} s$ vawould be, as far as I know, unattested elsewhere. Alternatively, Biridašwa could be easily interpreted as IIr. *priHta-Haćua- and as such Biryašwa *priHa-Haćua-, both names meaning 'whose horse is dear' (Mayrhofer 1966: 21; 1974: 19). These names are then comparable to the Vedic formulaic phrase Ved. áśvān prī- or to personal names such as Elam.-Ir. pirriyasba(pir-ri-ya-is-ba, pir-ri-as-ba) ${ }^{10}$ and Av. frīnāspa-. In this case a typological parallel could also be drawn with Old English frīd-hengest 'a horse well looked after' (Mayrhofer 1966: 21; Schmitt 1967: 243 f.).

Moreover, it is noteworthy to point out that an Aryan origin of compound names in *biri- is uncertain, because *bir- is a very productive element in the Hurrian language and onomastics (Gelb et al. 1943: $114 \mathrm{f}$; $\mathrm{BGH})$. Such an element would likely be Hurrian rather than Indo-Aryan according to Belardi (1951: 63). The same is true for Ariwana, probably the successor of Biridašwa, which is supposed to be interpreted as Early Indo-Aryan *ari-uana 'the one who conquers enemies' (Dumont apud O'Callaghan 1948: 151, no. 43). Both ar(i)-, deriving from the root aru- 'to give' (BGH: $41 \mathrm{ff}$.), and wan- occur in Hurrian personal names, especially in Nuzi tablets (e.g. $a-a r-h u, a-r a-a t-t u, u a-a n-t a-r a$ in Gelb et al. 1943: 24 ff., 170 ff., 203). The name Puruša, generally compared to Ved. púrușa- 'man', could be ascribed to Hurrian origin, since the element pur- is not uncommon in Hurrian onomastics (e.g. pur-ra-aš-he, pur-ni in Gelb et al. 1943: 118 f.). ${ }^{11}$

In summary, the analysis of these compound names has to take into account an intrinsic ambiguity, since the same name could be interpreted in one way or another. The correspondence between a given Mitanni-Aryan name and Vedic and Old Iranian names (or even free phrases) consequently is not always clear. Additionally, some personal names commonly interpreted as Aryan could be better explained as Hurrian.

9 For an overview on el-Amarna Letters, see Moran (1992). A new and up-to-date edition is provided by Rainey et al. (2015).

10 Pirriyasba is clearly an Iranian name, which has been found in Elamite tablets from Persepolis Fortification Archive (Mayrhofer 1973: 218, no. 8,1338).

11 In this respect, Mayrhofer is unconvinced by this correspondence (KEWA 2,312 f.). Moreover, Belardi (1951: 63, fn. 1) argues that, besides $p u-r u$-sa, similar proper names such as $a-r i-p u-r u-s ̌ a, p u-r a-s a$ and $p u-r i-s i$ would be attested in Hurrian onomastic documentation. Thus, according to him, the Nuzi name pu-ru-sa (also pu-ru-ú-za, $p u-r a-s a, p u-r a-a-s a$ ) would not be Indo-Aryan. 


\section{On the morphology and semantics of Mitanni-Aryan names}

In this section, I will focus on some interesting anthroponyms which preferably can be interpreted as Aryan appellatives. I will carry out both a morphological (§ 3.1) and semantic analysis (§ 3.2) in order to call attention to the major features of this subsystem of personal names.

\subsection{Morphological structures}

A morphological classification of Indo-Iranian personal names includes the three main categories of simple names, compound names and derivatives (e.g. Schmitt 1995a, 1995b; Sadovski 2006). ${ }^{12}$ Aryan names attested in the ancient Near East are chiefly exocentric compounds (especially possessive, labelled as bahúvrīhi according to the Indian terminology) in conformity with Vedic, Avestan or other archaic Indo-European languages such as Homeric Greek: e.g. Artatama ar-ta-ta-a-ma 'his abode is the rta' (cf. Ved.

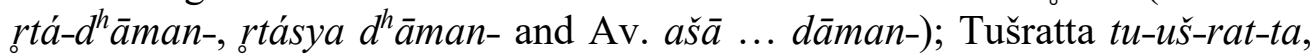
written also tu-iš-e-rat-ta, tu-uš-e-rat-ta, 'whose chariot is vehement' (cf. Ved. rát ${ }^{h} a$ - tveșá- and tveșárat ${ }^{h} a$-). Both the aforementioned Biridašwa and Biryašwa would be possessive compounds as well.

In this regard, several names are exocentric compounds ending in -atti, which could derive from IIr. * $a t^{h(i)} t i-$ 'guest' (cf. Ved. átithi-, Av. asti- 'id.'), as Mayrhofer (1966: 22) notices: e.g. Ašuratti $a \check{s}-s ̌ u-r a-a t-t i$ 'having a lord as his guest'; Indaratti in-tar-ra-at-ti 'having Indra as his guest'; Maryatti $m a-r i-a-a t-t i$ 'having a male warrior as his guest'; Mittaratti mi-it-ta-ra-at-ti 'having Mitra [or a friend] as his guest'. Personal names in *at ${ }^{h(i)} t i-$ are attested as well in Old Indo-Iranian languages: cf. Ved. mitrắtit ${ }^{h} i$ - in Ro 10,33 (PNRV 2,1,398); Av. gaiia $\bar{a} s t i-$ in Yt 13,112.140 (IPNB 1,46, no. 152); Av. vohuuasti- in Yt 13,96 (IPNB 1,99, no. 391).

Conversely, exocentric compound names with a preverb in the first member, the so-called éntheos type (Sadovski 2000 with literature), are less common in the Near Eastern documentation, while they are widespread in Vedic and Avestan. Thus, they would seem to be in fact geographically circumscribed: both $a$-bi-ra-at-ta /Abiratta/ 'facing chariots' (cf. Ved. $a b^{h} i$... $\left.r^{\prime} t^{h} a h\right)^{13}$ and pa-ra-at-ti /Paratti/ 'whose guest is ahead' (cf. Skr. prātit ${ }^{h} e y \bar{l}$ $[\mathrm{S} \bar{u}])^{14}$ are attested in Northern Syria but not elsewhere.

12 Anthroponyms will be distinguished with regard to their form and morphology, according to the typology provided by Schmitt (2005) and Sadovski (2006), respectively for Old Iranian and Indo-Iranian.

13 This proper name was borne also by the fifth Kassite king of the third dynasty in Babylon, a Kassite nobleman, and a person not further qualified in the Alalah tablets (Mayrhofer 1982a).

14 In this case the guest is probably Agni, the god who is always púrva- 'ahead' in Vedic mythology (Macdonell 1897: 96 f.; Pinault 1998: 455). 
Another group of personal names consists of endocentric compounds in which one member functions as the head and the other member as its modifier, attributing a property to the head. For instance, Aššuzzana $a \check{s}$ - $\breve{s} u-u z-z a-n a$ can be compared to OPers. Aspačanā $a-s-p-\bar{c}-n-h$ (IPNB 2,15, no. 15; Shahbazi 1987), probably a Median name attested also in Nebenüberlieferungen, meaning 'delighting in horses'; Yašdata ia-aš-da-ta presumably derives from IIr. *iaja-dāta- 'given by the sacrifice'; ${ }^{15}$ Indaruta in-tar-ú-da, en-dar-ú-ta, in-tar-ú-tá is identical to Vedic indrotá- 'helped by Indra' in Ro 8,68 [+] (PNRV 2,1,72; García Ramón 2017), Indra being a theonym both in Vedas and in Avestan texts.

Verbal governing compounds (or synthetische Komposita) are equally well attested: for instance, Artaššumara $a r-t a-a s ̌-s ̌ u-m a-r a$, a Mitannian king, son of King Šuttarna II and brother of Tušratta, ${ }^{16}$ and ar-ta-am-na Artamna, both meaning 'thinking of truth'. Artaššumara should be compared to unattested Ved. *rtá-smara- or Av. ašahe ... framaratahe in P 48 (Mayrhofer

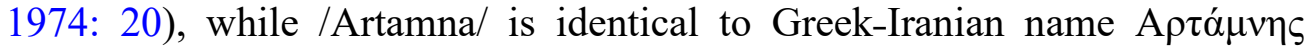
(Mayrhofer 1966: 22, fn. 5) and would recall a formula such as IIr. *rtam man- (see below). Anyhow, in governing compounds the verbal element could be either the first or the second member, such as Šattiwaza šat-ti-ú-a-za and Wasašatta $u-a-s a-s ̌ a-a t-t a$, both kings of Mitanni, respectively from IIr. *sāti-vāja and *vāja-sāta meaning 'getting the power' or 'reaching the prize'. These compound names would parallel Rigvedic formulas, such as văjam san ${ }^{i}$-, vāja-sáni-, ${ }^{\circ} s \bar{a}$-, and the Vedic compound vấjasāti- (Mayrhofer 1966: 21; 1974: 25, 31; 1982b: 79; see also § 3.2).

The copulative compounds (or dvandvas) do not occur in these sources, except for the theonym Mitrā-Varuña in the Šuppiluliuma-Šattiwaza treaty $(\S 1)$. Conversely, this type is attested in Indian and Iranian documentation (Schmitt 1995a: 654; 1995b: 680), although the status of copulative compounds in Iranian onomastics is still debated (see e.g. Cereti 2011).

Finally, single-stem full names, an archaic type inherited from Proto-IndoEuropean (Meier-Brügger 2003: $295 \mathrm{f}$.), occur in the system of the personal names as emerges from the Near Eastern documentation. For instance, Wazzi $\dot{u}-a-a z-z i$ should be compared to Ved. vajjín- 'racer' ${ }^{17}$ or even the patronymic name

15 This personal name appears to be debated. Dumont proposes to compare Yašdata either to Skt. yajñadatta- or vasudatta- 'given by the gods (the good ones)' without further explanation (Dumont apud O'Callaghan 1948: 152, no. 59). Mayrhofer (1966: $41 \mathrm{f}$.) points out that OPers. vahyašdāta could be a valuable comparandum accounting for $w / y$ alternation, since names in dāta- or datta- occur in Iranian and Indian documentation (IPNB 1,90, no. 351; 1,99 no. 386; 1,102, no. 401; 2,28 no. 56). Anyhow, El.-Ir. Yaštāta $i a-i \check{s}$-da-da for Ir. *yazdāta seems to be attested (Tavernier 2007: 365, no. 4,2,2016).

16 The same name is attested in the Alalah tablets ( $a r-t a-\check{s} u-m a-r a)$, who is hardly identical to the Mitanni-Aryan Artaššumara (Mayrhofer 1974: 20, fn. 44).

17 Vedic vấja- 'Wettkampf, Kampfpreis' (EWA 2,540 f.) occurs as first member of the compound name vájabandhu- 'zum Kampfe verbündet' in RoV 8,68,19 (PNRV 2,1,449). 
Audurta $a$-ú-du-ur-ta with lengthened-grade (Mayrhofer 1966: 130, no. 14).

To conclude, the morphological typology of the Mitanni-Aryan names is displayed in Table 1:

Table 1: Summary of the morphological types of the Mitanni-Aryan names

\begin{tabular}{|l|c|c|c|c|c|}
\hline & Single-stem & \multicolumn{4}{|c|}{ Compound names } \\
\cline { 3 - 6 } & names & Exocentric & $\begin{array}{c}\text { Verbal } \\
\text { governing }\end{array}$ & Endocentric & Copulative \\
\hline Example & Wazzi & Artatama & Artamna & Aššuzzana & Not attested \\
\hline
\end{tabular}

\subsection{Semantics of personal names}

Several names seem to contain either the stem IIr. *Haćua- 'horse' ${ }^{18}$ or the stem IIr. * ratHa- ( $\left.{ }^{*} \mathrm{rat}^{h} a-\right)$ 'chariot', being two fundamental means of war of the Aryan nobility (cf. the aforementioned names Aššuzzana and Abiratta). Moreover, the oldest personal names of Vedas and Avesta often incorporate terms referring to horses, chariots or horse accessories (Sadovski 2009). ${ }^{19}$ Indeed, both Old Indian and Old Iranian poetry inform on these bigae as a central feature of military life and religious rituals. ${ }^{20}$ According to the Vedas, horses and chariots were used in rituals such as Vedic aśvamed ${ }^{h} a$, a horse sacrifice ritual, and rājasūya, which included a chariot drive of the king. ${ }^{21}$ Horses seem to have played a prominent role also in Achaemenid rituals and beliefs: for instance, Achaemenid kings were carried on horse-drawn chariots. It goes without saying that phraseology relating to horses and chariots occurs in Old Indo-Iranian (ritual) poetry ${ }^{22}$ as well as in onomastic evidence. In this regard, Mitanni-Aryan compound names Šattiwaza and Wasašatta (*sāti-vāja-l *vāja-sāta-) match a Vedic collocation [REACH (sani) - PRIZE (vájam)], which precisely applies to contests (Pinault 2006; García Ramón 2017: 19 f.). ${ }^{23}$ For instance, in RV 46,1.2:

18 Unsurprisingly, a lexeme *aspa- is attested also in inherited Scythian personal names (Pinault 2008, particularly 108 f.).

19 Several Indian and Iranian proper names containing the term for horse have been listed, for example, in Justi (1895: 486) and Mayrhofer (1973, 1977, 2003), such as Ved. vrșanaśvá(PNRV 2,1,481) or Av. auruuat.aspa- (IPNB 1,26 f., no. 57), vǐštāspa- (IPNB 1,97, no. 379). Swennen (2002) highlights the importance of compound names in IIr. *Haćua- in the field of cultural reconstruction, especially of the Indo-Iranian pantheon.

20 The Avestan terminology of chariot races, which are clearly ritual races, have been discussed by Helmut Humbach in his edition of the Ga $\vartheta a s$, the oldest Avestan text (Humbach 1959).

21 Aryans did not employ chariots only for warfare. Nevertheless, evidence is lacking to determine whether chariots were actually employed in other activities such as ritual contests (Sparreboom 1985).

22 For a survey of the (sacred) horse in the ancient Indic and Iranian literature, see Swennen (2004).

23 Hintze (2000) provides an exhaustive study on the semantics of 'reward' in Old Iranian and Vedic Sanskrit texts. 
tvắm íd dhí hávāmahe

sātắ văjasya kārávaḥ /

tvắm vṛtréṣv indra sátpatim náras

tvấṃ kăș̣thāsv árvatah //

sá tvám naś citra vajrahasta $\mathrm{d}^{\mathrm{h}}$ rṣ̣nuyấ

mahá stavānó adrivạ̣ /

gắm áśvaṃ rathyàm indra sám kira

satrā vầjaṃ ná jigyúșe //

"Because it is just you that we bards call upon at the winning of the prize, / you, Indra, as master of settlements that our men (call upon) amid obstacles, you at the finish lines of our steed, / So you - o dazzling one with mace in hand, o possessor of the stone, being praised as the great one - boldly / heap up for us cow, horse, and chariotry altogether like a prize for the winner, o Indra." (Jamison \& Brereton 2014: 832)

and in $\mathrm{RV}_{0}$ 6,26,1:

śrud $^{h} \overline{1}$ na indra hváyāmasi tvā

mahó vấjasya sātaú vāvroṣānăhạ /

sám yád víśó 'yanta śúrasātā

ugrám nó 'vaḥ pắrye áhan dāḥ //

"Hear us, Indra. We are calling to you as we are "boiling over" at the winning of the great prize. / When the clans clash together at the contest of champions, give us mighty help on the decisive day." (Jamison \& Brereton 2014: 809)

It should also be noted that Mitannian onomastics seems to express relevant elements in addition to military ideology. As aforementioned, some exocentric compound names end in 'atti- 'guest' (< IIr. * $\left.a t^{h(i)} t i-\right):^{24}$ Ašuratti, Indaratti, Paratti and so on. Hospitality was a pivotal institution not only in Aryan society but also in Indo-European ideology (for instance, Schrader 1901: 269 ff.). Reciprocity relation between a host and a guest was significant in ancient societies, as witnessed by Indo-European poetics (Watkins 1995: 70 ff.). Thus, Mitanni-Aryan compound names in ${ }^{\circ}$ atti- closely reflect the importance of guest in Aryan and Indo-European ideology. Host is often considered as a potential ally among Aryan peoples, such as in RV 1,58,6:

dadhúh tvā bớrgavaḥ mấnuṣeșu á

rayím ná cắrum suhávam jáneb ${ }^{\mathrm{h}} \mathrm{yah}$ /

hótāram agne átit ${ }^{\mathrm{h}} \mathrm{im}$ váreṇyam

mitrám ná śévam divyấya jánmane //

"The Bhrgus installed you among the sons of Manu, dear like wealth, easy to invoke for the peoples, | as Hotar, o Agni, a guest worthy to be chosen, favorable like an ally to the divine race." (Jamison \& Brereton 2014: 175) 
Additionally, hospitality was conceived as a divine worship and usually god's names appear as the first members of compounds in ${ }^{\circ}$ atti-: e.g. Indaratti and Mittaratti, which clearly correspond to the Vedic personal name mitrấtithi-.

Even more importantly, these names occasionally parallel poetic formulas

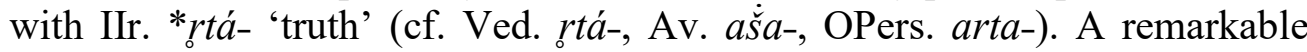
example is Artamna, the name of a Mitannian dynast, which interestingly should be compared to an inherited Indo-Iranian expression *rtam man- 'to think (of) truth' occurring both in Rgveda and Avesta: ${ }^{25}$

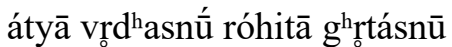
rótásya manye mánasā jávișt thā (RV 4,2,3)

"The two chestnut steeds of truth, strong(-backed), ghee-backed, I consider to be swiftest (even in comparison) with mind." (Jamison \& Brereton 2014: 559)

gūštā yō maṇtā aṣ̆ əm ahūmbiš vīduuă ahurā (Y 31,19)

"Le médecin de l'existence, l'initié, a entendu, lui qui a conçu Aša, ô Ahura." (Lecoq 2016: 735)

yōi nōit a ș̣ əm mainiiaṇtā aēibiiō dūirē vohū as manō (Y 34,8)

“Ceux qui ne pensent pas à Aša, Vohu Manah sera loin d'eux.” (Lecoq 2016: 748)

Therefore, this formula would be contained in Artamanya ar-ta-ma-an-ia, a prince of Ziribašani, and in the aforementioned Artaššumara with a different verbal root, namely *smar-. Yet, the element *rtá- occurs in another case, i.e. Artatama, which would exactly correspond to a Vedic compound rtád $\bar{a}$ man'whose abode is the rtá-'. Allegedly, Mitanni and Syrian rulers' personal names widely recall the Indo-Iranian concept of truth, which was predominant in Indo-Iranian ideology. As is known, rightness means both '(cosmic or social) order' and 'correctness', partially overlapping with the semantic field of 'truthfulness' in the Indo-Iranian community (Schlerath \& Skjærvø 1987). Mitanni sovereigns and Syrian potentates could be represented as guarantors of truth or, possibly, of the "Cosmic Order" inasmuch they were bearers of rtá-names. In this way, their names should be compared to Achaemenid throne-names (Schmitt 1982) such as x̌̌ayařšan- 'he who is ruling over heroes' and rtaxšaça'whose rule is through the truth' with their respective programmatic message.

\section{Concluding remarks}

In the foregoing, I have attempted to show that Mitanni-Aryan names correspond to the typology drawn for Vedic and Old Iranian both from morphological and semantic point of view. Indeed, the system of the formation of these names agrees to a great extent with that known from

25 Also, rotám manvānà (Ro 138,1$)$. 
Vedas and Avesta. Exocentric compounds and verbal governing compounds already proved to be relatively frequent, while simple-stem names are fairly rare. No copulative compound name occurs.

Moreover, personal names and epithets can shed some light on certain key concepts of a given social milieu. As a matter of fact, Mitanni-Aryan personal names preserved several features which go back to Indo-Iranian royal ideology - horses, chariots, prizes, the rtá- ('truth') and so on (for instance, Widengren 1959). This is hardly surprising considering that we are dealing with names of kings and rulers. Thus, relics of Indo-Iranian ritual poetry seem to survive in these personal names. Dichter-, Ritualsprache and Namenbuch are supposed to be strongly connected to each other in Indo-Iranian or more generally Indo-European traditions, as appellatives and proper names mostly reflect earlier phraseological collocations (also, Schmitt 1967; Campanile 1999; Sadovski 2017 with literature).

However, these results are to be interpreted cautiously. According to Sadovski (2009: 115 f.):

Proper names and epithets can in fact shed light on the position of certain key concepts contained in them among the values of the persons concerned (more precisely, of the generation of their parents), especially of the authors of the respective texts, and their social milieu. But they allow only very general, sometimes rather trivial, conclusions in purely economic regard. Nevertheless, they often contain some of the earliest attestations of the relevant lexical material, as in the case of Old Persian, where the mass of personal names and their derivatives attested in the various traditions (above all, beside OPers itself, in Elamic or New and Late Babylonian sources) plays a decisive role within the linguistic material as a whole.

In conclusion, Aryan names from the ancient Near East allow us to trace ideological features of Indo-Iranian heritage back to the 2nd millennium $\mathrm{BC}$, but they cannot provide any clue as to an (Indo-)Aryan domination over Hurrian principalities, given also the lack of historical sources.

\section{Acknowledgement}

I am grateful to professors Paolo Di Giovine and Marianna Pozza, as well as to my colleagues Serena Barchi and Silvia Brambilla, for the insightful comments on an earlier version of this paper. Special thanks to the two anonymous peer reviewers for their comments and suggestions. All remaining errors are my own. 


\section{References}

Beckman, Gary M. 1996. Hittite diplomatic texts. Atlanta: Scholars Press.

Belardi, Walter. 1951. Sui nomi ari nell'Asia anteriore antica. In Miscellanea Giovanni Galbiati. Vol. III. Archeologia, storia, filologia classica e bizantina, filologia orientale, glottologia [Festschrift for Giovanni Galbiati. Vol. III. Archaeology, history, classical and byzantine philology, oriental studies and historical linguistics], 55-74. Milano: Hoepli.

$\mathrm{BGH}=$ Richter 2012 .

Burrow, Thomas. 1973. The Sanskrit language. London: Faber \& Faber. (1st ed. 1955.)

Campanile, Enrico. 1999. Saggi di linguistica comparativa e ricostruzione culturale [Essays on comparative linguistics and cultural reconstruction]. Roma - Pisa: Istituti editoriali e poligrafici internazionali.

Cancik-Kirschbaum, Eva Christiane \& Brisch, Nicole \& Eidem, Jesper. 2014. Constituent, confederate and conquered space. The emergence of the Mittani State. Berlin - Boston: de Gruyter.

Cassin, Elena \& Glassner, Jean-Jacques. 1977. Anthroponymie et anthropologie de Nuzi. Malibu: Undena Publications.

Cereti, Carlo Giovanni. 2011. Copulative compounds in Iranian onomastics. In Krisch, Thomas (ed.), Indogermanistik und Linguistik im Dialog. Akten der XIII. Fachtagung der Indogermanische Gesselschaft vom 21. bis 27. September 2008 in Salzburg, 110-119. Wiesbaden: Reichert.

Diakonov, Igor M. 1972. Review of Kammenhuber (1968). Orientalia 41(1), 91-121.

Draffkorn, Anne Elizabeth. 1959. Hurrian and Hurrians at Alalah: An ethnolinguistic analysis. University of Pennsylvania. (Doctoral dissertation.)

Dumézil, Georges. 1952. Les dieux souverains des indo-européens. Paris: Presses Universitaires de France.

Eichner, Heiner. 2009. Parallelen zu indoiranischen religiösen Konzepten in Texten der Hethiter. In Pirart, Eric \& Tremblay, Xavier (eds.), Zarathusthra entre l'Inde et l'Iran: Études indo-iraniennes et indo-européennes offertes à Jean Kellens à l'occasion de son $65^{e}$ anniversaire, 57-67. Wiesbaden: Reichert.

EWA $=$ Mayrhofer 1992-2000.

Freu, Jacques. 2003. Histoire du Mitanni. Paris: L'Harmattan.

García Ramón, José Luis. 2017. Old Indo-Aryan lexicon in the Ancient Near East: Proto-Indo-European, Anatolian and Core Indo-European. Atti del Sodalizio Glottologico Milanese 10, 17-33.

Gelb, Ignace J. \& Purves, Pierre M. \& MacRae, Allan A. 1943. Nuzi personal names. Chicago: University of Chicago Press. 
Gentile, Simone. 2018. I nomi arî di Mitanni. Una riconsiderazione della questione alla luce dei dati più recenti [Rethinking Mitanni-Aryan names, with new data]. Sapienza Università di Roma. (MA Dissertation.) Giorgieri, Mauro. 1999. Zu den hurritischen Personennamen in den AmarnaBriefen. Studi Micenei ed Egeo-Anatolici 41, 63-83.

Gotō, Toshifumi. 2009. Aśvín- and Nấsatya- in the Rgveda and their prehistoric background. In Osada, Toshiki (ed.), Linguistics, archaeology and human past in South Asia, 199-226. Delhi: Manohar.

Hintze, Almut. 2000. ,Lohn' im Indoiranischen. Eine semantische Studie des Rigveda und Avesta. Wiesbaden: Reichert.

Humbach, Helmut 1959. Die Gathas des Zarathustra, 2 vols. Heidelberg: Winter.

IPNB = Mayrhofer 1977 .

Jamison, Stephanie W. \& Brereton, Joel P. 2014. The Rigveda: The earliest religious poetry of India, 3 vols. Oxford: Oxford University Press.

Justi, Ferdinand. 1895. Iranisches Namenbuch. Marburg: N.G. Elwertsche Verlagsbuchhandlung.

Kammenhuber, Anneliese. 1968. Die Arier im vorderen Orient. Heidelberg: Winter.

KEWA = Mayrhofer 1956-1980.

Laroche, Emmanuel. 1966. Les noms des Hittites. Paris: Klincksieck.

Lecoq, Pierre. 2016. Les livres de l'Avesta. Textes sacrés des Zoroastriens. Paris: Éditions du Cerf.

Macdonell, Arthur A. 1897. Vedic mythology. Strassburg: Trübner.

Mayrhofer, Manfred. 1956-1980. Kurzgefasstes etymologisches Wörterbuch des Altindischen, 4 vols. Heidelberg: Winter.

Mayrhofer, Manfred. 1965. Sichtung vorderasiatisch-arischer Personennamen. Indogermanische Forschungen 70(2), 146-163.

Mayrhofer, Manfred. 1966. Die Indo-Arier im alten Vorderasien: Mit einer analytischen Bibliographie. Wiesbaden: Harrassowitz.

Mayrhofer, Manfred. 1973. Onomastica Persepolitana: Das Altiranische Namengut der Persepolis-Tafelchen. Wien: Verlag der Österreichischen Akademie der Wissenschaften.

Mayrhofer, Manfred. 1974. Die Arier im Vorderen Orient - ein Mythos? Mit einem bibliographischen Supplement. Wien: Verlag der Österreichischen Akademie der Wissenschaften.

Mayrhofer, Manfred. 1977. Die altiranischen Namen. (= Iranisches Personennamenbuch, Band I, Faszikel 1-3). Wien: Verlag der Österreichischen Akademie der Wissenschaften.

Mayrhofer, Manfred. 1982a. Abiratta(̌̌). In Encyclopcedia Iranica, I/2, 218 (http://www.iranicaonline.org/articles/abirattas-proper-name-said-to-beof-indo-aryan-origin) (Accessed 2020-03-24.)

Mayrhofer, Manfred. 1982b. Welches Material aus dem Indo-arischen von Mitanni verbleibt für eine selektive Darstellung? In Neu, Erich (ed.), 
Investigationes philologicae et comparativae: Gedenkschrift für Heinz Kronasser, 72-90. Wiesbaden: Harrassowitz.

Mayrhofer, Manfred. 1992-2000. Etymologisches Wörterbuch des Altindoarischen, 3 vols. Heidelberg: Winter.

Mayrhofer, Manfred. 2003. Die Personennamen in der Rgveda-Samhitāa: Sicheres und Zweifelhaftes. München: Verlag der Bayerischen Akademie der Wissenschaften.

Meier-Brügger, Michael. 2003. Indo-European linguistics. Berlin - New York: de Gruyter.

Meyer, Eduard. 1908. Die ältesten datierten Zeugnisse der iranischen Sprache. Zeitschrift für vergleichende Sprachforschung auf dem Gebiete der Indogermanischen Sprachen 42(1), 1-27.

Moran, William L. 1992. The Amarna letters. Baltimore: Johns Hopkins University Press.

O'Callaghan, Roger T. 1948. Aram Naharaim: A contribution to the history of Upper Mesopotamia in the second millennium B.C. With an Appendix on Indo-Aryan names. Roma: Pontificium Institutum Biblicum.

Pinault, Georges-Jean. 1998. Le nom indo-iranien de l'hôte. In Meid, Wolfgang (ed.), Sprache und Kultur der Indogermanen. Akten der X. Fachtagung der Indogermanischen Gesellschaft, Innsbruck, 2228.9.1996, 451-477. Innsbruck: Institut für Sprachwissenschaft der Universität Innsbruck.

Pinault, Georges-Jean. 2006. Compétition poétique et poétique de la competition. In Pinault, Georges-Jean \& Petit, Daniel (eds.), La langue poétique indo-européenne. Actes du Colloque de travail de la Société des Etudes Indo-Europeennes (Indogermanische Gesellshaft / Society for Indo-European Studies): Paris, 22-24 octobre 2003, 367-411. Leuven Paris: Peeters.

Pinault, Georges-Jean. 2008. La langue des Scythes et le nom des Arimaspes. Comptes rendus des séances de l'Académie des Inscriptions et Belles-Lettres, 152(1), 105-136.

Pirart, Éric. 1995. Les Nāsatya. Vol. I. Les noms des Aśvins. Genève: Droz.

PNRV = Mayrhofer 2003.

Rainey, Anson F. \& Schniedewind, William M. \& Cochavi-Rainey, Zipora. 2015. The El-Amarna correspondence: A new edition of the cuneiform letters from the site of El-Amarna based on collations of all extant tablets. Leiden - Boston: Brill.

Richter, Thomas. 2012. Bibliographisches Glossar des Hurritischen. Wiesbaden: Harrassowitz.

Sadovski, Velizar. 2000. Die exozentrischen Zusammensetzungen mit Vorderglied Präverb/Präposition im Rogveda: Entheos-Komposita und präpositionale Rektionskomposita. In Forssman, Bernhard \& Plath, Robert (eds.), Indoarisch, Iranisch und die Indogermanistik. Arbeitstagung der 
Indogermanischen Gesellschaft vom 2. bis 5. Oktober 1997 in Erlangen, 455-473. Wiesbaden: Reichert.

Sadovski, Velizar. 2006. On morphological structures in the system of personal names. In Panaino, Antonio \& Zipoli, Riccardo (eds.), Proceedings of the 5th Conference of the Societas Iranologica Europcea, held in Ravenna, 6-11 October 2003: Classical \& contemporary Iranian studies. Vol. II. Classical \& contemporary Iranian studies, 541-555. Milano: Mimesis.

Sadovski, Velizar. 2009. On horses and chariots in Ancient Indian and Iranian personal names. In Fragner, Bert G. \& Kauz, Ralph \& Ptak, Roderich \& Schottenhammer, Angela (eds.), Pferde in Asien: Geschichte, Handel und Kultur / Horses in Asia: History, trade and culture, 113-129. Wien: Verlag der Österreichischen Akademie der Wissenschaften.

Sadovski, Velizar. 2017. "The columns of Rta": Indo-Iranian lexicon and phraseology in the ritual poetry of the Avesta, Veda and beyond. In Hajnal, Ivo \& Kölligan, Daniel \& Zipser, Katharina (eds.), Miscellanea indogermanica: Festschrift für José Luis García Ramón zum 65. Geburtstag, 715-743. Innsbruck: Innsbrucker Beiträge zur Sprachwissenschaft.

Schlerath, Bernfried \& Skjærvø, Prods Oktor. 1987. As̆a. In Encyclopcedia Iranica, II/7, 694-696. (http://www.iranicaonline.org/articles/asa-meanstruth-in-avestan) (Accessed 2020-03-24.)

Schmitt, Rüdiger. 1967. Dichtung und Dichtersprache in indogermanischer Zeit. Wiesbaden: Harrassowitz.

Schmitt, Rüdiger. 1982. Achaemenid throne-names. AIQN 42, 83-95.

Schmitt, Rüdiger. 1995a. Alt- und mittelindoarische Namen. In Eichler, Ernst \& Hilty, Gerold \& Löffler, Heinrich \& Steger Hugo \& Zgusta, Ladislav (eds.), Namenforschung / Name studies / Les noms propres. Ein internationales Handbuch zur Onomastik / An international handbook of onomastics / Manuel international d'onomastique, vol. I, 645-657. Berlin - New York: de Gruyter.

Schmitt, Rüdiger. 1995b. Iranische Namen. In Eichler, Ernst \& Hilty, Gerold \& Löffler, Heinrich \& Steger Hugo \& Zgusta, Ladislav (eds.), Namenforschung / Name studies / Les noms propres. Ein internationales Handbuch zur Onomastik / An international handbook of onomastics / Manuel international d'onomastique, vol. I, 678-690. Berlin - New York: de Gruyter.

Schmitt, Rüdiger. 2005. Personal names, Iranian. Pre-Islamic names: general. In Encyclopcedia Iranica. (http://www.iranicaonline.org/articles/personalnames-iranian-i) (Accessed 2020-03-24.)

Schrader, Otto. 1901. Reallexikon der Indogermanischen Altertumskunde: Grundzuge einer Kultur- und Volkergeschichte Alteuropas. Strassburg: Trübner.

Shahbazi, Alireza Shapour. 1987. Aspačanā. In Encyclopcedia Iranica, II/8, 786 787. (http://www.iranicaonline.org/articles/aspacana-elamite-asbazana- 
babylonian-aspasini-greek-aspathines-possibly-already-in-nuzi-assuzzanaa-senior-official-) (Accessed 2020-03-24.)

Sparreboom, M. 1985. Chariots in the Veda. Leiden: Brill.

Swennen, Philippe. 2002. Notes d'onomastique indo-iranienne ancienne. In

Huyse, Philip (ed.), Iran: Questions et connaissances. Actes du IV congrès européen des études iraniennes, organisé par la Societas Iranologica Europaea, Paris, 6-10 septembre 1999. Monographic number of Studia Iranica. Cahiers 25, 163-174.

Swennen, Philippe. 2004. D'Indra à Tištrya: Portrait et évolution du cheval sacré dans les mythes indo-iraniens anciens. Paris: de Boccard.

Tavernier, Jan. 2007. Iranica in the Achaemenid period (ca. 550-330 B.C.): Lexicon of Old Iranian proper names and loanwords, attested in non-Iranian texts. Leuven: Peeters.

Thieme, Paul. 1960. The "Aryan" gods of the Mitanni treaties. Journal of the American Oriental Society 80(4), 301-317.

van Koppen, Frans. 2004. The geography of the slave trade and Northern Mesopotamia in the Late Old Babylonian period. In Hunger, Hermann \& Pruzsinsky, Regine (eds.), Mesopotamian Dark Age revisited. Proceedings of an International Conference of SCIEM 2000 (Vienna 8th-9th November 2002), 9-33. Wien: Verlag der Österreichischen Akademie der Wissenschaften.

von Dassow, Eva. 2008. State and society in the Late Bronze Age. Alalah under the Mittani Empire. Bethesda: CDL Press. (Studies on the Civilization and Culture of Nuzi and the Hurrians 17.)

von Dassow, Eva. 2014. Levantine polities under Mittanian hegemony. In Cancik-Kirschbaum, Eva \& Brisch, Nicole \& Eidem, Jesper (eds.), Constituent, confederate, and conquered space: The emergence of the Mittani State, 11-32. Berlin - Boston: de Gruyter.

Watkins, Calvert. 1995. How to kill a dragon: Aspects of Indo-European poetics. Oxford - New York: Oxford University Press.

Widengren, Geo. 1959. The sacral kingship of Iran. In Edsman, Carl-Martin (ed.), The sacral kingship / La Regalità Sacra: Contributions to the central theme of the VIII ${ }^{\text {th }}$ International Congress for the History of Religions (Rome, April 1955) / Contributi al tema dell'VIII Congresso Internazionale di Storia delle Religioni (Roma, Aprile 1955), 242-257. Leiden: Brill.

Wilhelm, Gernot. 1989. The Hurrians. Warminster: Aris \& Phillips.

Wilhelm, Gernot. 1995. The Kingdom of Mitanni in second-millennium Upper Mesopotamia. In Sasson, Jack M. (ed.), Civilizations of the ancient Near East, 1243-1254. New York: Scribner. 


\section{Appendix: Corpus of Mitanni-Aryan personal names}

1. /Abiratta/

Transliteration(s): a-bi-ra-at-ta.

Etymology: * $a b^{h} i-r a t^{h} a$ - 'facing chariots' (cf. Ved. $a b^{h} i$... rát $t^{h} a h$ ).

2. /Aitagama/

Transliteration(s): a-i-țu-kà-ma, a-i-țu-kà-ma, a-tak-ka-ma, i-ta-ka-ma, e-ta-ga-ma, i-tá-kà-ma, e-tá-kà-ma, i-ták-kà-ma, i-ta-at-ka-ma.

Etymology: *aita-gama- 'running like an antelope' (?). ${ }^{26}$

3. /Aittara/

Transliteration(s): a-i-it-ta-ra, a-i-it-ta-a-ra, a-i-da-ra, at-ta-ra, a-it-ta-ra, a-i-da-ra, at-ta-ra.

Etymology: *aitareia- (cf. Skt. itarā- 'the other (of two)' or a proper name and also Skt. patronymic aitareya-).

4. /Artamanya/

Transliteration(s): ar-ta-ma-an-ia.

Etymology: *rta-mania- 'thinking of truth' (cf. Ved. rtám man- or OAv. yo mantā as்̀m [Y 31,19]).

5. /Artamna/

Transliteration(s): ar-ta-am-na.

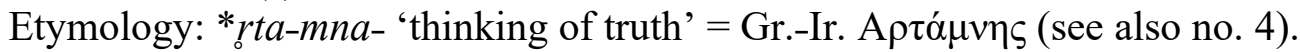

6. /Artaššumara/

Transliteration(s): ar-ta-aš-šu-ma-ra.

Etymology: *rta-smara- 'thinking of truth' (cf. Av. ašahe ... framarotahe [P. 48]).

7. /Artatama/

Transliteration(s): ar-ta-ta-a-ma.

Etymology: *rta-dhaman- 'whose abode is the rta' (cf. Ved. rtá-d $d^{h} \bar{a} m a n-$, rtásya d'äman-; Av. ašā ... dāman-).

8. /Artaya/

Transliteration(s): ar-ta-ia.

Etymology: *rtaiant- 'acting according to the truth' (cf. Ved. rtáyant-).

26 This personal name, if it refers to the same person, is more probably Semitic (Weber quoted in O'Callaghan 1948: 151, no. 41) rather than (Indo-)Aryan. Anyhow, it is problematic to determine whether it is Aryan (Mayrhofer 1966: 30). 
9. /Aššuratti/

Transliteration(s): aš-šu-ra-at-ti.

Etymology: *asura-att ${ }^{h}$ 'having a lord as his guest' (cf. Ved. ásura- átit ${ }^{h} i$-).

10. /Aššuzzana/

Transliteration(s): aš-šu-uz-za-na.

Etymology: *Haćua-cana- 'delighting in horses' = OPers. aspačanā.

11. /Audurta/

Transliteration(s): a-ú-du-ur-ta.

Etymology: a patronymic of *udrta (?).

12. /Awaššura/

Transliteration(s): a-ú-a-šu-ra, a-ú-a-aš-šu-ra.

Etymology: *avas-ćūra- 'helping heroes'.

13. /Biridašwa/

Transliteration(s): bi-ri-da-aš-wa.

Etymology: *priHta-Haćua- 'whose horse is dear' (cf. Ved. áśvān prī-; Av. frīnāspa-).

14. /Biryamašda/

Transliteration(s): bi-ir-ia-ma-aš-da.

Etymology: *priHa-mazd $\hat{d}^{h} a$ - 'whose wisdom is beloved' (cf. Ved. priyá-med ${ }^{h} a-$ ).

15. /Biryašwa/

Transliteration(s): bi-ri-ia-aš-šu-wa.

Etymology: *priHa-Haćua- 'whose horse is dear' = El.-Ir. pirriyasba- (see no. 13).

16. /Biryatti/

Transliteration(s): bi-ri-at-ti, bi-ri-a-at-ti.

Etymology: *priHa-atthi- 'having a friend as his guest' (cf. Ved. priyáátit $^{h} i-;$ Skt. priyātit ${ }^{h} i-;$ Av. friia- asti-).

17. /Deuwatti/

Transliteration(s): te-ú-at-ti.

Etymology: *daiua-att ${ }^{h}$ - 'having a god as his guest' (cf. Skt. devātit ${ }^{h} i$-).

18. /Indratti/

Transliteration(s): in-tar-ra-at-ti.

Etymology: *indra-att ${ }^{h}$ - 'having Indra as his guest'. 
19. /Indaruta/

Transliteration(s): in-tar-ú-da, en-dar-ú-ta, in-tar-ú-tá.

Etymology: *indra-ūta- 'upheld by Indra' (cf. Ved. indrotá-).

20. Maryatti

Transliteration(s): ma-ri-a-at-ti.

Etymology: *maria-att ${ }^{h}$ - 'having a marya [young warrior] as his guest'.

21. Mittaratti

Transliteration(s): mi-it-ta-ra-at-ti.

Etymology: *mitra-atth $i$ - 'having Mitra [or a friend] as his guest' (cf. Ved. mitrắtit ${ }^{h}$-).

22. /Paratti/

Transliteration(s): pa-ra-at-ti.

Etymology: *pra-atth $i-$ 'whose guest is forward' (cf. Skr. prätit ${ }^{h}$ eyī-).

23. /S̆attawaza/

Transliteration(s): ̌a-at-ta-ú-a-az-za， ša-at-ta-ú-az-za， šá-at-ta-ú-az-za, ša-ad-du-a-az-za.

Etymology: *sāta-vāja- 'reaching a prize' (cf. Ved. vấjasāti-, vấjam san ${ }^{i}$, ${ }^{\circ}$ sáa-, vāja-sáni-, etc.).

24. /Šattiwaza/

Transliteration(s): šat-ti-ú-a-za.

Etymology: *sāti-vāja- 'reaching a prize' (see no. 23).

25. /Šattuara/

Translietration(s): šat-tu-a-ra.

Etymology: *sāta-vāra 'reaching the prize' (cf. Ved. vắryā vấjeșu sanișāmahe [RV 3,11,9], vấryā ... siṣāsati [RoV 3,11,9]). ${ }^{27}$

26. /Šauššatar/

Transliteration(s): ša-uš-sa-ta-at-tar, ša-uš-ta-at-tar.

Etymology: propatronymic from *su-st ${ }^{h} \bar{t} t a r-$ 'whose horse driver is good' (cf. Ved. $\left.s t^{h} \bar{a} t a r-\right)^{28}$

27 This etymology has been proposed by Mayrhofer (1974: 28, fn. 82). Conversely, Burrow (31973: 28) compare this personal name to Ved. sátvan- 'powerful, victorious', hence 'warrior', while Dumont (apud O'Callaghan 1948: 149, no. 7) connects /Šattuara/ to Skt. satvara- 'swift'.

28 Previously, Šauššatar was interpreted as *sau-ksatra-, a plausible patronymic of Ved. sukșatrá- 'having a good dominion', actually attested (Dumont apud O'Callaghan 1948: 149, no. 6; Mayrhofer 1965: 152 f., fn. 26). This personal name would then correlate with Gr.-Ir. 'O $\xi \dot{\alpha} \vartheta \rho \eta$ s. Notwithstanding, Mayrhofer (1974: 25 f., particularly fn. 71) mentions *su-sthätar- as the most likely proposal. 
27. /Šubandu/

Transliteration(s): šu-ba-an-di, šu-ba-an-du.

Etymology: *su-band ${ }^{h} u$ - 'whose relative is good' (cf. Ved. subándhu-; Skt. subandhu-).

28. /Šuryatti/

Transliteration(s): šu-ri-a-at-ti.

Etymology: *suHria-att ${ }^{h}$-'having the sunlike [Agni] as his guest' ${ }^{29}$

29. /Šuwardatta/

Transliteration(s): šu-uaa-ar-da-ta, šu-ar-da-tu.

Etymology: *suHar-d̄ata 'given by the sun' (cf. Ep. Skt. süryadatta-).

30. /Šuwatti/

Transliteration(s): šu-una-at-ti.

Etymology: *su-att ${ }^{h}$ - 'whose guest is good' (cf. Av. vohuuasti-).

31. /Tušratta/

Transliteration(s): tù-uš-rat-ta, du-uš-rat-ta, tu-iš-e-rat-ta, tu-uš-e-rat-ta.

Etymology: *tvaiśa-rat ${ }^{h} a$ - 'whose chariot is vehement' (cf. Ved. ráth $a$ - tveșá-).

32. /Wasašatta/

Transliteration(s): u-a-sa-ša-at-ta.

Etymology: *vāja-sāta 'reaching a prize' (see no. 23 and 24).

33. /Wazzi/

Transliteration(s): ú-a-az-zi

Etymology: *vājin- 'prize-winner' (cf. Ved. vājín-'racer').

34. /Yašdata/

Transliteration(s): i ia-aš-da-ta.

Etymology: *yaja-dāta- 'given by the sacrifice' (cf. Skt. yajñadatta-; probably, also El.-Ir. ia-ǐ̌-da-da).

29 Usually Agni is to be identified with the sun (Macdonell 1897: 93). 


\section{Abbreviations}

Av.

El.-Ir.

Gr.-Ir.

IIr.

OPers.

RV

Skt.

$\mathrm{Sū}$

Ved.

$\mathrm{Y}$

$\mathrm{Yt}$
Avestan

Elamite-Iranian

Greek-Iranian

Indo-Iranian

Old Persian

Rgveda

Sanskrit

Sūtra

Vedic

Yasna

Yašt 